\title{
Assessment of agronomic characters and yield in garlic genotypes under agro- climatic conditions of Mingora-Swat Pakistan
}

\author{
Noor Habib Khan ${ }^{1 *}$, Iqbal Hussain ${ }^{2}$, Sajid Khan ${ }^{3}$, Rahmani Gul ${ }^{1}$, Izhar \\ Ullah $^{3}$, Saeed Ul Haq ${ }^{3}$ and Sidra Saleem ${ }^{3}$ \\ 1. Agricultural Research Institute, Mingora, Swat-Pakistan \\ 2. Sichwan Agricultural University-China \\ 3. Department of Horticulture, The University of Agriculture Peshawar-Pakistan \\ *Corresponding author's email: noorhabib808@gmail.com \\ Citation \\ Noor Habib Khan, Iqbal Hussain, Sajid Khan, Rahmani Gul, Izhar Ullah, Saeed Ul Haq and Sidra Saleem. \\ Assessment of agronomic characters and yield in garlic genotypes under agro-climatic conditions of Mingora- \\ Swat Pakistan. Pure and Applied Biology. Vol. 10, Issue 3, pp657-667. \\ http://dx.doi.org/10.19045/bspab.2021.100068
}

\begin{tabular}{llll}
\hline \hline Received: 06/07/2020 & Revised: 08/10/2020 & Accepted: 17/11/2020 & Online First: 26/11/2020 \\
\hline \hline
\end{tabular}

\section{Abstract}

Garlic different genotypes were evaluated for their agronomic traits against a local cultivar for two consecutive years at Agricultural Research Institute Mingora, Swat, Pakistan. Seven genotypes (NARC-1, NARC-3, NARC-4, NARC-5, Swat Garlic-1, Swat White and Lehsan Gulabi) were used for the trial. Genotypes vary significantly in plant height, number of leaves plant ${ }^{-1}$, stem thickness, leaf area, bulb weight, number of cloves bulb ${ }^{-1}$, clove weight and yield tons ha ${ }^{-1}$. Yield of the new genotypes were 2-3 times higher than the existing cultivar 'Lehsan Gulabi'. "Swat White' and 'NARC-1' have outclassed other genotypes producing a yield of 24.9 and 24.0 tons $\mathrm{ha}^{-1}$ respectively. Better vegetative growth, high number of cloves and bulb weight in these genotypes contributed to higher yield. The results indicated that the new genotypes could perform better for the desired traits than the existing cultivar, therefore the local cultivar should be replaced with these new genotypes for improve garlic yield.

Keywords: Allium sativum; Agronomic characters; Bulb weight; Bulb yield; Genotypes

\section{Introduction}

Onion and Garlic (Allium sativum) belongs to the family Alliaceae. Garlic is one of the most popular spices in the world and is known for its medicinal values. It is has been used as food condiment and medicine for over 5000 years [1]. It is one of the oldest known horticultural crops. It is reported that in ancient Egypt, the workers who had to build the great pyramids were fed garlic daily. Some writings suggest that garlic was grown in China as far back as 4000 years ago. Bible mentions that the Hebrews enjoyed their food with garlic. Recently during world War I and
World War II soldiers were given garlic as antiseptic to help prevent gangrene. Today garlic is used to help prevent atherosclerosis, improve high blood pressure and reduce colds, coughs and bronchitis [2]. Garlic grows wild in Central Asian Republics of Kyrgyzstan, Tajikistan, Turkmenistan, and Uzbekistan and also in Afghanistan and northern region of Pakistan. This region is known as its "Center of origin" In this region garlic is believed to be originated and flourished in wild. Garlic has many germplasm that differ in bulb size, bulb color, number of cloves per bulb and storage life [3]. 
These varieties have broadly divided into two groups, hard neck and soft neck cultivars.

Chromosomal studies of garlic revealed its diploid set of chromosomes $2 n=16$ [4]. Garlic is vegetatively propagated through cloves. The genetic variations are the outcome of sexual reproduction in wild ancestors [5] Clonal selection is an important breeding method for varietal improvement. A superior clone selected and identified once, its maintenance through clonal propagation is secure and easy [6]. Lack of improved germplasm is one of the main reasons of low garlic yield in Pakistan. 'Lehsan Gulabi' being the sole soft neck cultivar registered. Farmers use self- generated cloves which differ in bulb size, color, shape, number of cloves per bulb and length in storage. These germplasm are not of the same color, size and shape and thus having little market value. From these variations some superior clones has been selected for varietal improvement. The aim of this trial was to assess the agronomic traits and yield of the new garlic genotypes. The selected germplasm would be subjected to more trials for the purpose of registration and variety approval.

\section{Materials and Methods}

The trial was conducted at Agricultural Research Institute Mingora, Swat during two consecutive growing seasons of 2015-16 and 2016-17. Experimental site is located at $34.3^{\circ}-$ $35.53^{\circ}$ North Latitude and 71.5-72.5 Longitude and 906 meter above sea level. Seven genotypes were set in randomized complete block design (RCBD) and were replicated three times. Plants were spaced 10 $\mathrm{cm}$ apart in rows and $30 \mathrm{~cm}$ between rows in plot size of $3 \times 1 \mathrm{~m}^{2}$. Farm yard manure was applied at the time of soil preparation @ 15 ton ha ${ }^{-1}$. All phosphorus and potash and half dose of nitrogen were applied at planting. The remaining half dose of nitrogen was applied after first hand weeding and hoeing. Cultural practices were applied when needed. Data were recorded on yield and yield associated parameters on randomly selected 15 plants in the middle rows. Data was statistically analyzed using statistical software STATISTIX 8.1. Least significant test with 5 $\%$ level of significance was used to compare the means [7].

\section{Results and Discussion}

\section{Plant height, number of leaves plant ${ }^{-1}$ and leaf area $\left(\mathrm{cm}^{2}\right)$}

Plant height, number of leaves plant ${ }^{-1}$ and leaf area were found significant at 5\% level of probability (Fig. 1, 2, 3). 'Swat White' produced maximum height of $93.3 \mathrm{~cm}$, maximum number of 11.6 leaves plant ${ }^{-1}$ with maximum leaf area of $114.9 \mathrm{~cm}^{2}$, while minimum plant height of $64.7 \mathrm{~cm}$ with minimum number of leaves 6.5 were recorded in 'Lehsan Gulabi'. Leaf area was also minimum $44.7 \mathrm{~cm}^{2}$ in 'Lehsan Gulabi'. [8] Found plant height and number of leaves plant $^{-1}$ ranging from 86.50-108-50 and 10.0013.25 respectively in various genotypes. According to [3] plant height shows vigor of the germplasm. According to their results, plant height decreases as the vigor decreases. According to [9] rise in plant height increases leaf area which leads to more yield. Leaf area was positively and significantly correlated with plant height, plant biomass but not yield and plant height and leaf area were not correlated with yield [10]. Plant height and number of leaves plant $^{-1}$ were different in different genotypes and the growing environment also influences plant height. As all the tested germplasms were evaluated in the same location and environment, so the difference in plant height and number of leaves appeared to be genetic. [11, 12] also found significant differences in plant height and number of leaves plant $^{-1}$ in various germplasms.

\section{Stem thickness (mm)}

The mean data regarding stem thickness showed significant variation among the genotypes (Fig. 4). Year as a source of variation was not significant. Maximum stem thickness of $15.9 \mathrm{~mm}$ was found in 'Swat White' while minimum stem thickness of 7.0 $\mathrm{mm}$ was recorded in 'Lehsan Gulabi'. [13] stated that stem thickness in onion indicates the failure of the plant to complete the bulb formation process and such bulbs do not undergo dormancy. This problem arises because of slow growth or short growing period. According to [14] every cultivar has specific photoperiodic requirement for bulb production. When the minimum photoperiodic and temperature requirement of the cultivar does not meet, plants continue to grow 
without bulb formation which leads to thickening of the stems. In garlic the phenomenon appeared to be different. As neck is formed from the bases of the leaves thus bigger leaves with more leaf area make thick stems. Hard neck cultivars have usually bigger leaves with more leave area and thick stem compared to soft neck cultivars. 'Lehsan Gulabi' in this study is the soft neck cultivar and have thinner stem compared to other genotypes.

\section{Days to maturity}

Data regarding days to maturity in 2015-16 and 2016-17 and its mean is presented in (Table 1a \& b). Results showed that genotypes vary significantly in days taken to maturity; while year as source of variation was not significant $(\mathrm{p}<0.05)$ 'NARC-1' took maximum 206.3 days from transplanting to harvesting while 'Lehsan Gulabi' matured 16 days earlier and took 190.8 days to harvesting (Fig. 5).

\section{Single bulb weight (g)}

Single bulb weights varied in different genotypes in both the growing seasons and the year effect was also found significant at 5 $\%$ level of probability. Maximum single bulb weight of $78.42 \mathrm{~g}$ was recorded in 'NARC-1', while 'Swat White' and 'Swat Garlic' were statistically at par having bulb weight of $70.05 \mathrm{~g}$ and $68.05 \mathrm{~g}$ respectively. Minimum bulb weight of $20.10 \mathrm{~g}$ was recorded in 'Lehsan Gulabi' (Fig. 6). [15] assessed phenotypic traits of ten diverse cultivars in garlic across 12 locations in United States and Canada and found that bulb size and circumference vary with site.[16] reported positive and significant correlation among bulb yield, clove weight and bulb weight and concluded that genotypes with high bulb weight and more number of cloves gave more yield.

\section{Number of cloves bulb ${ }^{-1}$ and single clove weight}

Genotypes significantly influenced number of cloves per bulb and single clove weight in both the years while the year effect was nonsignificant. 'Swat White' and 'Swat Garlic' produced maximum number of 14.1 and 13.4 cloves per bulb respectively (Fig. 7, 8). Cloves per bulb in 'NARC-1' were minimum 6.5 but more than 3 times higher in weight than the cloves of 'Swat White' and 'Swat Garlic'. 'NARC-1' is elephant garlic which produce big size bulbs and cloves and hence, popular among the farmers. Late planting or spring planting of elephant garlic may not produce separate cloves but will form large single undifferentiated clove which sometimes grow to the size of a baseball [17] Clove weight contribute to bulb weight which lead to higher production. Clove number appeared less important. Varieties differ in number of cloves per bulb and bulb weight [1]. According to [16] genotypes with more bulb weight and number of cloves produced more yield.

\section{Yield (tons ha-1)}

Yield tons ha ${ }^{-1}$ was significant $(p<.0 .05)$ in various genotypes in both the test years and the year effect was not significant (Fig. 9). Yield of the new genotypes were 2-3 times higher than the existing cultivar 'Lehsan Gulabi' 'Swat White' and 'NARC-1' have outclassed other genotypes producing a yield of 24.9 and 24.0 tons ha ${ }^{-1}$. Better vegetative growth, higher number of cloves and bulb weight in these genotypes contributed to more yield. High yield in garlic depends on sufficient size and quality of the initial stock. As garlic is propagated vegetatively through cloves, keeping cloves pathogen free is very challenging [18-20]. Initial planting stock of 'Lehsan Gulabi' was not satisfactory which may the cause of its lower yield. Yield is correlated with bulb diameter, number of cloves, clove diameter and bulb weight [21]. 
Table 1a. Agronomic traits of garlic genotypes

\begin{tabular}{|c|c|c|c|c|c|c|c|c|c|c|c|c|c|c|c|}
\hline \multirow{2}{*}{$\begin{array}{c}\text { Treatments/ } \\
\text { Characters }\end{array}$} & \multicolumn{3}{|c|}{ Plant Height (cm) } & \multicolumn{3}{|c|}{ No. of Leaves/Plant } & \multicolumn{3}{|c|}{ Leaf Area $\left(\mathrm{cm}^{2}\right)$} & \multicolumn{3}{|c|}{ Stem thickness (mm) } & \multicolumn{3}{|c|}{ Days to Maturity } \\
\hline & 2015-16 & 2016-17 & Mean & $\begin{array}{c}2015- \\
16\end{array}$ & $\begin{array}{c}2016- \\
17\end{array}$ & Mean & $\begin{array}{c}2015- \\
16\end{array}$ & $\begin{array}{c}2016- \\
17\end{array}$ & Mean & $\begin{array}{c}2015- \\
16\end{array}$ & $\begin{array}{c}2016- \\
17\end{array}$ & Mean & $\begin{array}{c}2015- \\
16\end{array}$ & $\begin{array}{c}\text { 2016- } \\
17\end{array}$ & Mean \\
\hline NARC-1 & $68.8 \mathrm{~d}$ & $76.9 \mathrm{c}$ & $72.8 \mathrm{~d}$ & $8.4 \mathrm{~d}$ & $8.0 \mathrm{~d}$ & $8.2 \mathrm{~d}$ & $95.8 \mathrm{a}$ & $\begin{array}{c}100.9 \\
\mathrm{bc}\end{array}$ & $98.4 \mathrm{~b}$ & $16.5 \mathrm{a}$ & $14.8 \mathrm{ab}$ & $15.7 \mathrm{a}$ & $207.6 \mathrm{a}$ & $205.0 \mathrm{a}$ & $206.3 \mathrm{a}$ \\
\hline NARC-3 & $75.1 \mathrm{~cd}$ & $84.3 \mathrm{~b}$ & $79.7 \mathrm{c}$ & $11.2 \mathrm{ab}$ & $8.6 \mathrm{~cd}$ & $9.9 \mathrm{bc}$ & $102.1 \mathrm{a}$ & $\begin{array}{c}110.7 \\
\mathrm{ab}\end{array}$ & $\begin{array}{c}106.4 \\
\mathrm{ab}\end{array}$ & $\begin{array}{l}15.0 \\
a b c\end{array}$ & $11.8 \mathrm{bc}$ & $13.4 \mathrm{bc}$ & $193.3 \mathrm{c}$ & $\begin{array}{c}195.0 \\
b c\end{array}$ & $194.1 \mathrm{c}$ \\
\hline NARC-4 & $77.6 \mathrm{bc}$ & $84.5 \mathrm{~b}$ & $81.0 \mathrm{c}$ & $10.2 \mathrm{c}$ & $9.7 \mathrm{bc}$ & $9.9 \mathrm{bc}$ & $100.2 \mathrm{a}$ & $\begin{array}{c}103.4 \\
\mathrm{bc}\end{array}$ & $101.8 \mathrm{~b}$ & $15.3 \mathrm{ab}$ & $\begin{array}{l}13.2 \\
\mathrm{abc}\end{array}$ & $14.2 \mathrm{ab}$ & $192.0 \mathrm{c}$ & $\begin{array}{c}192.3 \\
\mathrm{~cd}\end{array}$ & $\begin{array}{c}192.1 \\
\mathrm{de}\end{array}$ \\
\hline NARC-5 & $76.0 \mathrm{bc}$ & $81.0 \mathrm{bc}$ & $78.5 \mathrm{c}$ & $10.3 \mathrm{c}$ & $8.2 \mathrm{~cd}$ & $9.2 \mathrm{c}$ & $93.3 \mathrm{a}$ & $96.2 \mathrm{c}$ & $94.7 \mathrm{~b}$ & $13.3 \mathrm{c}$ & $11.4 \mathrm{c}$ & $12.3 \mathrm{c}$ & $192.6 \mathrm{c}$ & $\begin{array}{c}193.0 \\
\mathrm{~cd}\end{array}$ & $\begin{array}{c}192.8 \\
\mathrm{~cd}\end{array}$ \\
\hline Swat Garlic 1 & $82.0 \mathrm{~b}$ & $91.4 \mathrm{a}$ & $86.7 \mathrm{~b}$ & $10.7 \mathrm{bc}$ & $10.3 \mathrm{ab}$ & $10.5 \mathrm{~b}$ & $114.4 \mathrm{a}$ & $115.5 \mathrm{a}$ & $114.9 \mathrm{a}$ & $14.4 \mathrm{bc}$ & $14.6 \mathrm{ab}$ & $14.5 \mathrm{ab}$ & $195.6 \mathrm{~b}$ & $196.6 \mathrm{~b}$ & $196.1 \mathrm{~b}$ \\
\hline Swat White & $92.8 \mathrm{a}$ & $93.9 \mathrm{a}$ & $93.3 \mathrm{a}$ & $11.5 \mathrm{a}$ & $11.7 \mathrm{a}$ & $11.6 \mathrm{a}$ & $93.9 \mathrm{a}$ & $\begin{array}{c}111.7 \\
\mathrm{ab}\end{array}$ & $102.8 \mathrm{~b}$ & $15.9 \mathrm{ab}$ & $16.0 \mathrm{a}$ & $15.9 \mathrm{a}$ & $197.3 \mathrm{~b}$ & $196.3 \mathrm{~b}$ & $196.8 \mathrm{~b}$ \\
\hline $\begin{array}{l}\text { Lehsan } \\
\text { Gulabi }\end{array}$ & $61.1 \mathrm{e}$ & $68.3 \mathrm{~d}$ & $64.7 \mathrm{e}$ & $6.5 \mathrm{e}$ & $7.4 \mathrm{~d}$ & $6.9 \mathrm{e}$ & $45.1 \mathrm{~b}$ & $44.3 \mathrm{~d}$ & $44.7 \mathrm{c}$ & $6.4 \mathrm{~d}$ & $7.5 \mathrm{~d}$ & $7.0 \mathrm{~d}$ & $191.6 \mathrm{c}$ & $190.0 \mathrm{~d}$ & $190.8 \mathrm{e}$ \\
\hline LSD & 6.7 & 4.9 & 3.9 & 0.70 & 1.7 & 0.87 & 22.91 & 10.96 & 12.0 & 1.80 & 3.02 & 2.07 & 1.97 & 3.97 & 2.36 \\
\hline Year & 76.2 & 82.9 & 79.5 & 9.85 & 9.1 & 9.51 & 92.16 & 97.56 & 94.8 & 13.88 & 12.63 & 13.27 & 195.76 & 195.48 & 195.62 \\
\hline $\begin{array}{c}\text { Year } x \\
\text { Genotypes }\end{array}$ & - & - & $*$ & - & - & ns & - & - & ns & - & - & ns & - & - & Ns \\
\hline
\end{tabular}

ns: non-significant at $5 \%$ level of probability, * significant at $5 \%$ level of probability 
Pure Appl. Biol., 10(3):657-667, September, 2021 http://dx.doi.org/10.19045/bspab.2021.100068

Table 1b. Agronomic traits of garlic genotypes

\begin{tabular}{|c|c|c|c|c|c|c|c|c|c|c|c|c|}
\hline \multirow{2}{*}{$\begin{array}{c}\begin{array}{c}\text { Treatments/ } \\
\text { Characters }\end{array} \\
\text { Genotypes }\end{array}$} & \multicolumn{3}{|c|}{ Single Bulb Weight (g) } & \multicolumn{3}{|c|}{ Number of Cloves/ Bulb } & \multicolumn{3}{|c|}{ Single Clove Weight } & \multicolumn{3}{|c|}{ Yield tons/ha } \\
\hline & 2015-16 & 2016-17 & Mean & $\begin{array}{c}2015- \\
16\end{array}$ & $\begin{array}{c}\text { 2016- } \\
17\end{array}$ & Mean & $\begin{array}{c}2015- \\
16\end{array}$ & $\begin{array}{c}2016- \\
17\end{array}$ & Mean & 2015-16 & $\begin{array}{c}2016- \\
17 \\
\end{array}$ & Mean \\
\hline NARC-1 & $71.14 \mathrm{a}$ & $85.70 \mathrm{a}$ & $78.42 \mathrm{a}$ & $6.6 \mathrm{c}$ & $6.5 \mathrm{c}$ & $6.5 \mathrm{c}$ & $14.7 \mathrm{a}$ & $14.2 \mathrm{a}$ & $14.5 \mathrm{a}$ & $22.0 \mathrm{a}$ & $26.0 \mathrm{a}$ & $24.0 \mathrm{a}$ \\
\hline NARC-3 & $55.12 \mathrm{~d}$ & $59.47 \mathrm{c}$ & $\begin{array}{c}57.29 \\
\mathrm{~cd}\end{array}$ & $12.5 \mathrm{~b}$ & $11.9 \mathrm{~b}$ & $12.2 \mathrm{~b}$ & $4.0 \mathrm{c}$ & $4.1 \mathrm{~b}$ & $4.0 \mathrm{~b}$ & $16.5 \mathrm{~b}$ & $18.3 \mathrm{~d}$ & $17.4 \mathrm{c}$ \\
\hline NARC-4 & $58.29 \mathrm{~cd}$ & $59.20 \mathrm{~cd}$ & $58.75 \mathrm{c}$ & $12.6 \mathrm{~b}$ & $13.4 \mathrm{a}$ & $13.0 \mathrm{ab}$ & $4.8 \mathrm{~b}$ & $3.8 \mathrm{~b}$ & $4.3 \mathrm{~b}$ & $16.7 \mathrm{~b}$ & $20.4 \mathrm{c}$ & $18.5 \mathrm{c}$ \\
\hline NARC-5 & $55.12 \mathrm{~d}$ & $52.77 \mathrm{~d}$ & $\begin{array}{c}53.94 \\
\mathrm{~d}\end{array}$ & $12.6 \mathrm{~b}$ & $11.7 \mathrm{~b}$ & $12.2 \mathrm{~b}$ & $4.2 \mathrm{bc}$ & $3.5 \mathrm{~b}$ & $3.9 \mathrm{~b}$ & $15.2 \mathrm{~b}$ & $\begin{array}{c}19.2 \\
\mathrm{~cd}\end{array}$ & $17.2 \mathrm{c}$ \\
\hline Swat Garlic 1 & $62.13 \mathrm{bc}$ & $73.97 \mathrm{~b}$ & $\begin{array}{c}68.05 \\
b\end{array}$ & $\begin{array}{c}13.4 \\
\mathrm{ab}\end{array}$ & $13.5 \mathrm{a}$ & $13.4 \mathrm{a}$ & $4.4 \mathrm{bc}$ & $3.6 \mathrm{~b}$ & $4.1 \mathrm{~b}$ & $21.7 \mathrm{a}$ & $22.7 \mathrm{~b}$ & $22.2 \mathrm{~b}$ \\
\hline Swat White & $65.50 \mathrm{ab}$ & $74.60 \mathrm{~b}$ & $\begin{array}{c}70.05 \\
\mathrm{~b}\end{array}$ & $\begin{array}{c}14.0 \\
\mathrm{ab}\end{array}$ & $14.1 \mathrm{a}$ & $14.1 \mathrm{a}$ & $3.9 \mathrm{c}$ & $4.1 \mathrm{~b}$ & $4.0 \mathrm{~b}$ & $24.5 \mathrm{a}$ & $25.4 \mathrm{a}$ & $24.9 \mathrm{a}$ \\
\hline Lehsan Gulabi & $20.79 \mathrm{e}$ & $19.40 \mathrm{e}$ & $20.10 \mathrm{e}$ & $15.1 \mathrm{a}$ & $11.8 \mathrm{~b}$ & $13.4 \mathrm{a}$ & $2.1 \mathrm{~d}$ & $1.5 \mathrm{c}$ & $1.8 \mathrm{c}$ & $9.9 \mathrm{c}$ & $7.7 \mathrm{e}$ & $8.8 \mathrm{~d}$ \\
\hline LSD & 55.44 & 60.73 & 58.09 & 1.97 & 1.4 & 1.17 & 0.85 & 0.91 & 0.77 & 2.89 & 2.04 & 1.63 \\
\hline Year & $47.45 \mathrm{~b}$ & $60.34 \mathrm{a}$ & 53.90 & 12.41 & 11.87 & 12.14 & 5.47 & 4.99 & 5.23 & 18.11 & 19.96 & 19.04 \\
\hline Year $\times$ Genotypes & - & - & $*$ & - & - & ns & - & - & ns & - & - & ns \\
\hline
\end{tabular}

ns: non-significant at 5\% level of probability, *significant at 5\% level of probability 
Khan et al.

(a)

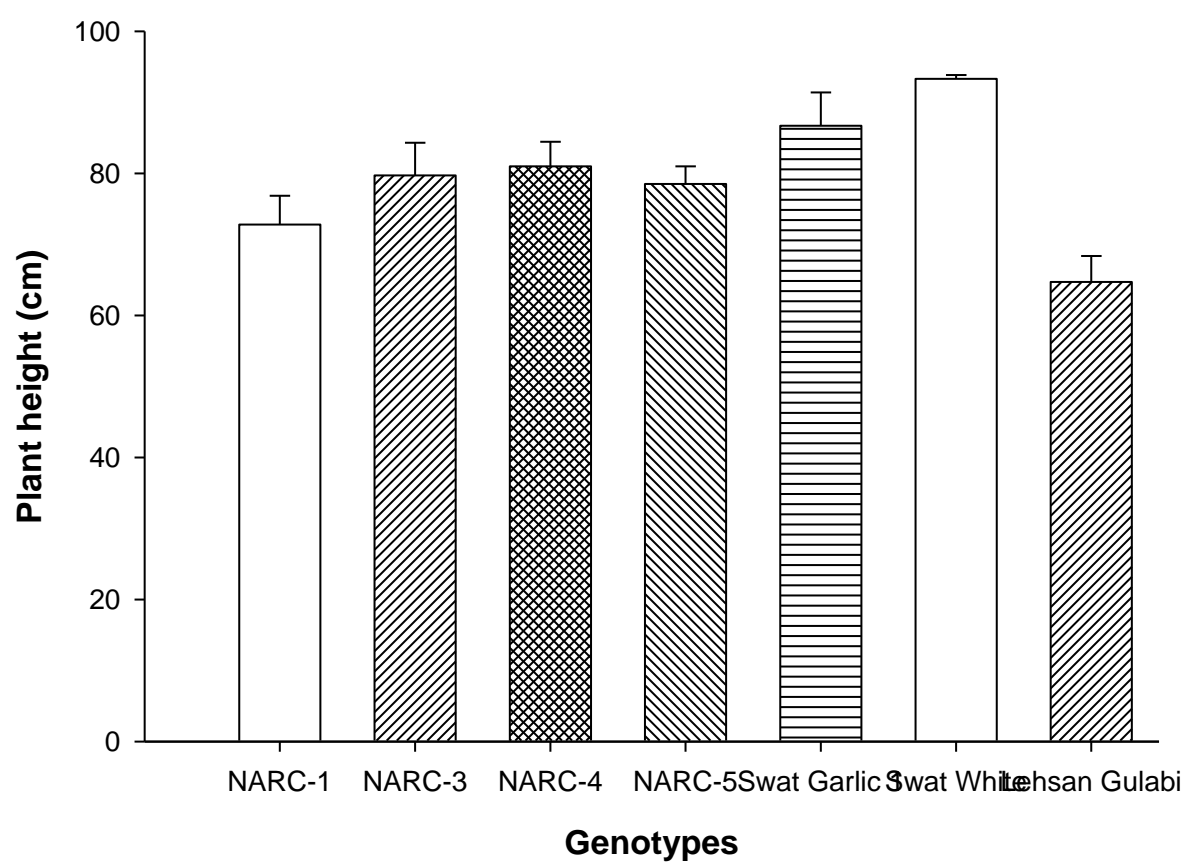

Figure 1. Mean data of plant height of different genotypes in both season (2015-2016)

(b)

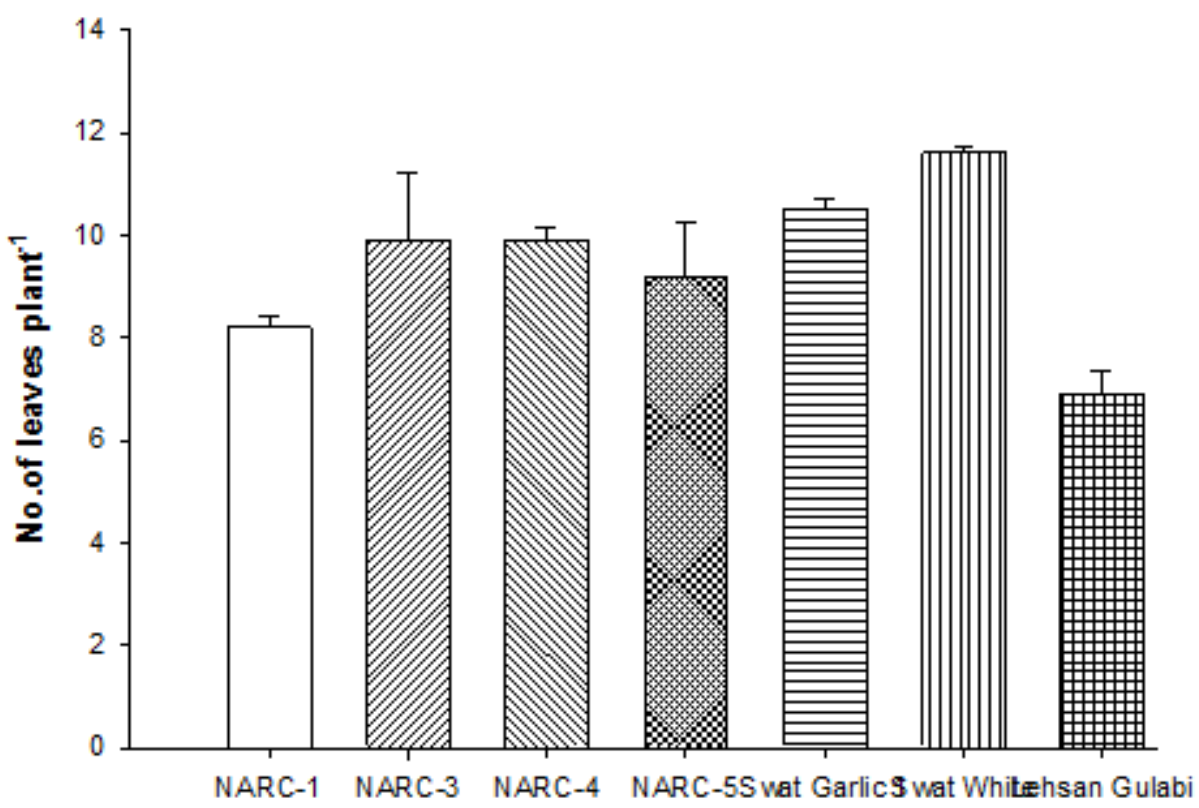

Genotypes

Figure 2. Mean data of No. of leaves plant $^{-1}$ of different genotypes in both season (20152016) 
(c)

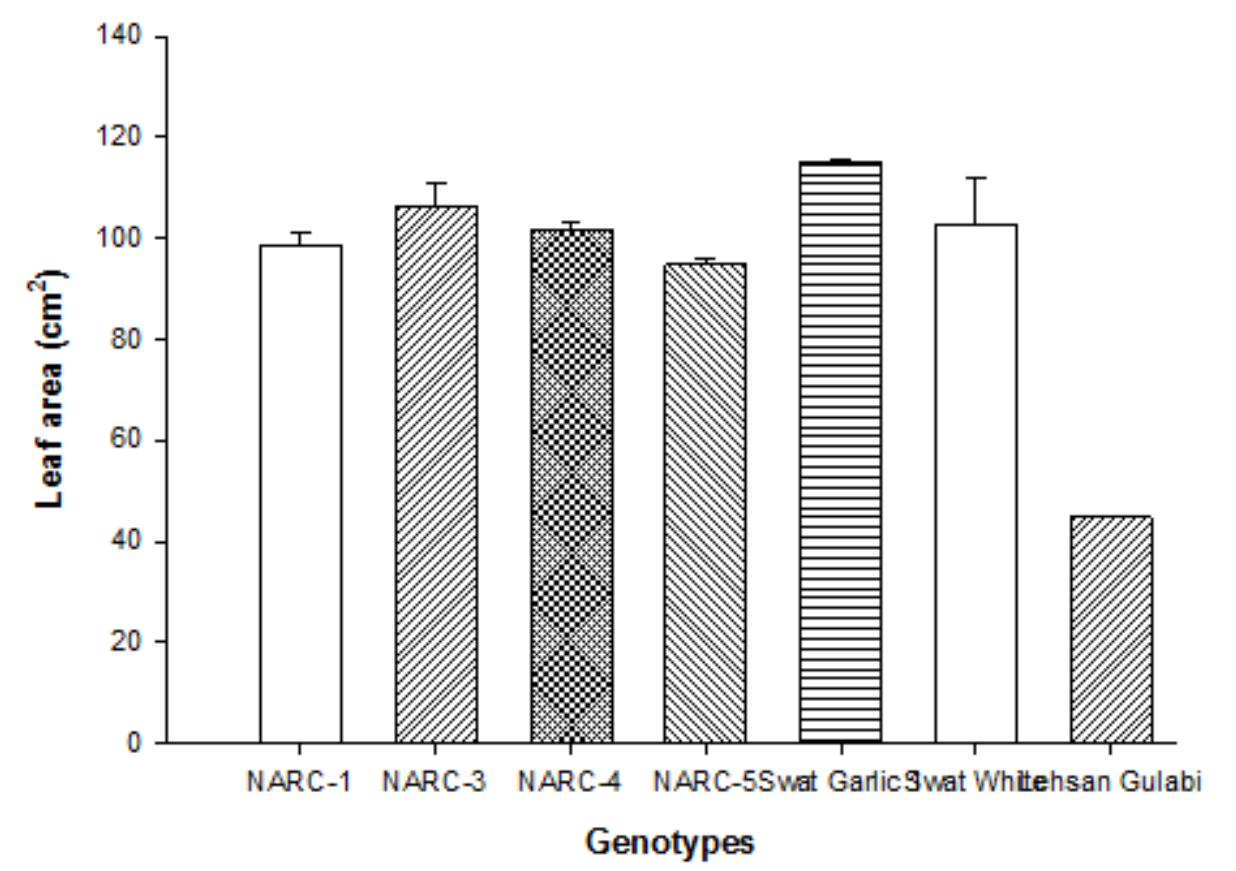

Figure 3. Mean data of leaf area $\left(\mathrm{cm}^{2}\right)$ of different genotypes in both season (2015-2016)

(d)

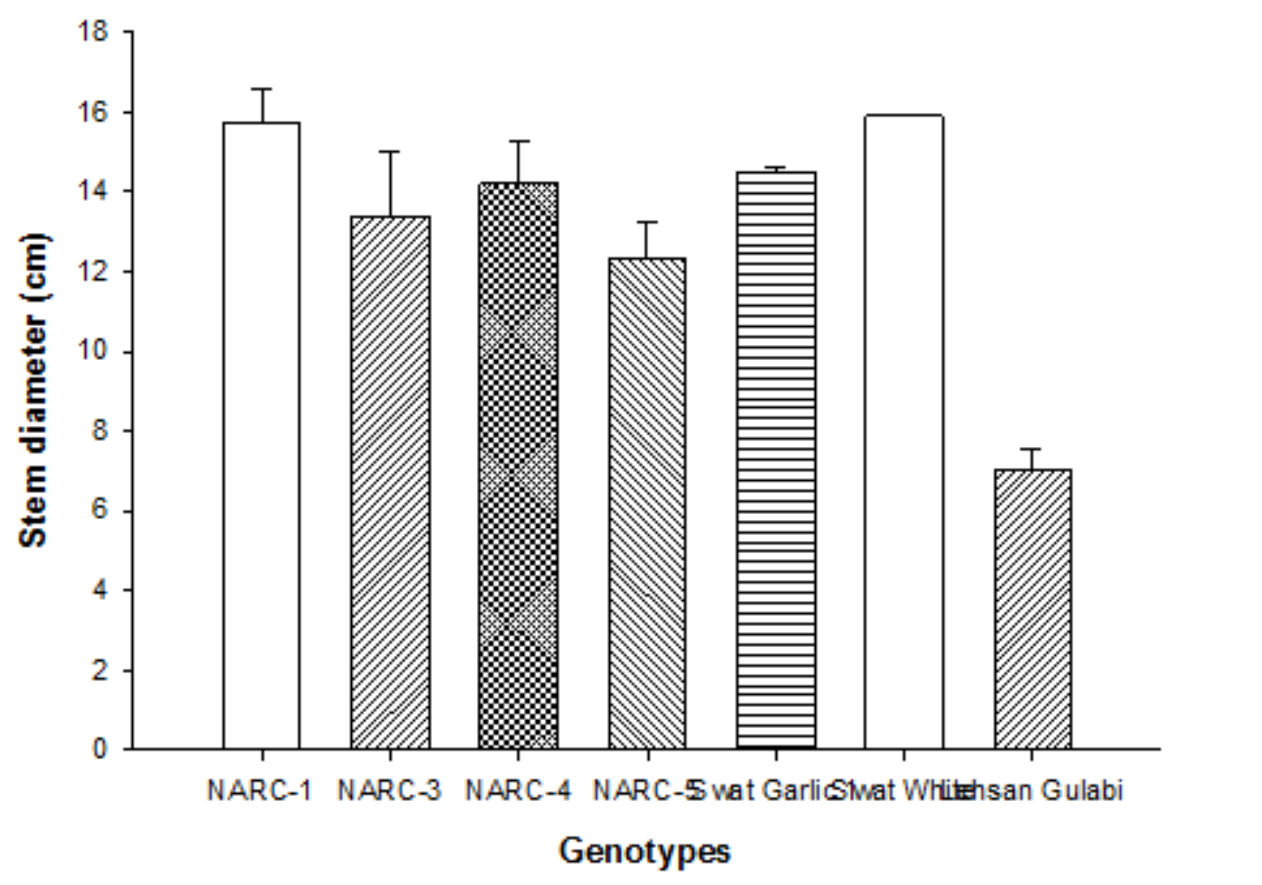

Figure 4. Mean data of stem diameter $\left(\mathrm{cm}^{3}\right)$ of different genotypes in both season (20152016) 
Khan et al.

(f)

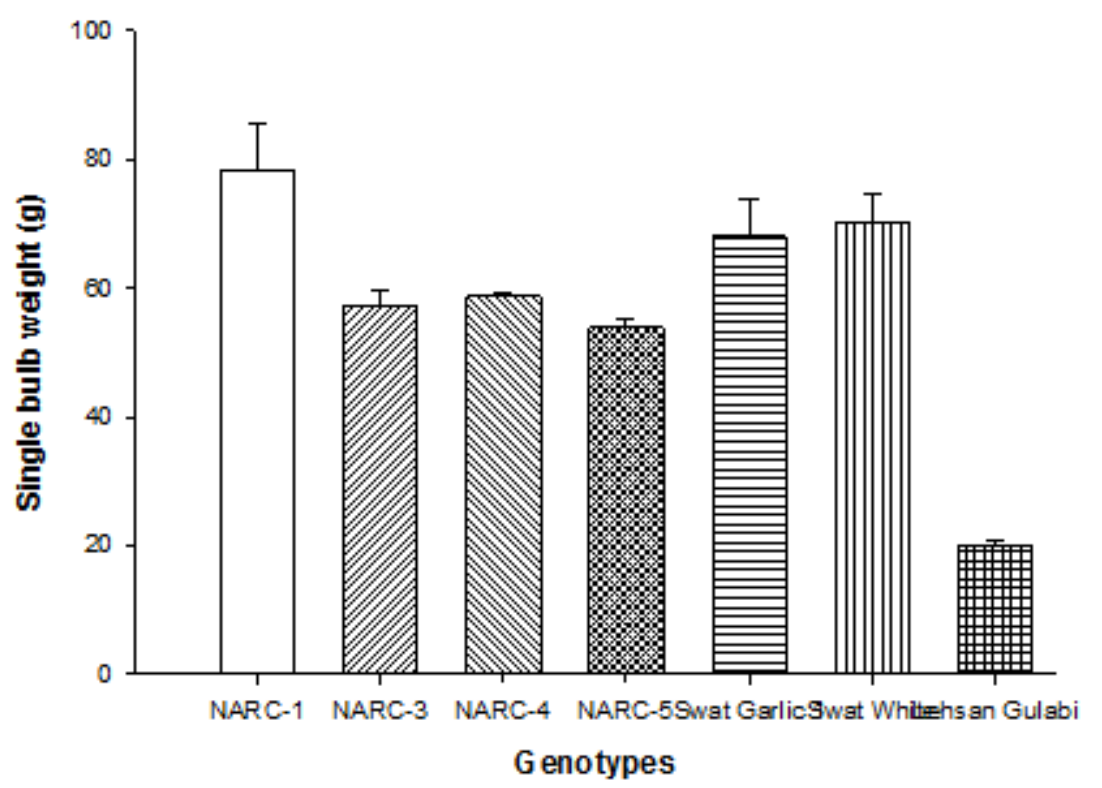

Figure 5. Mean data of single bulb weight (g) of different genotypes in both season (20152016)

(e)

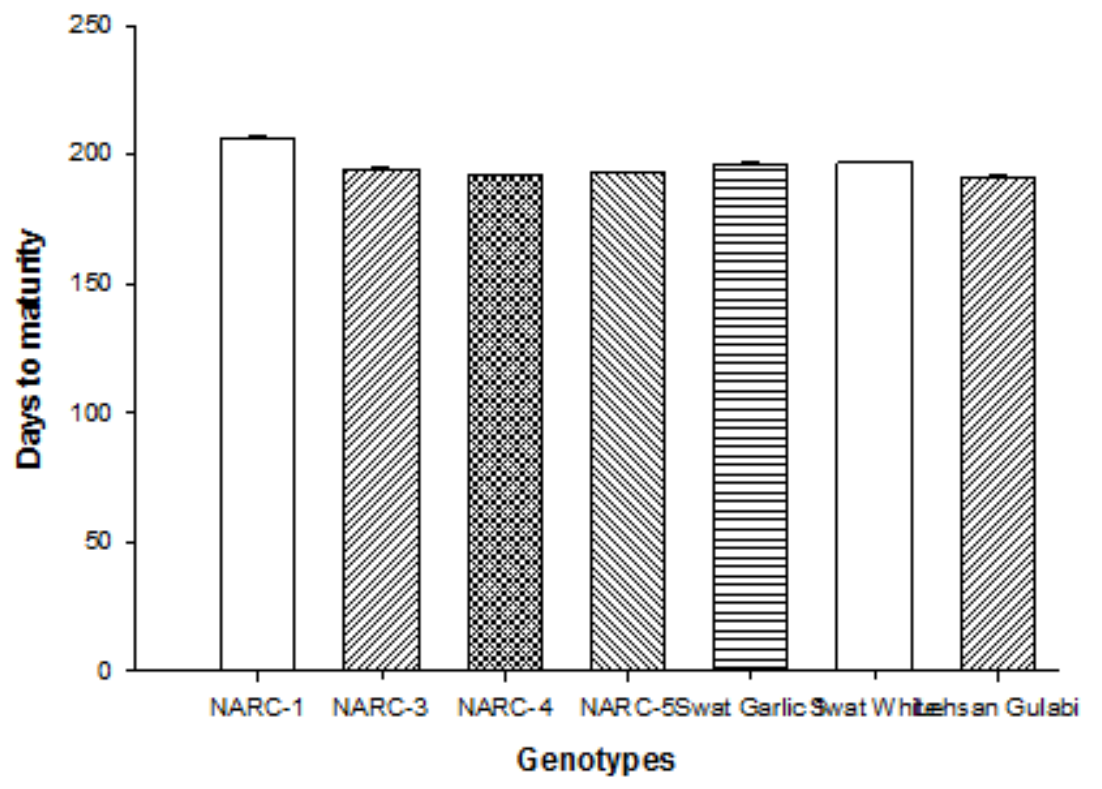

Figure 6. Mean data of Days to maturity of different genotypes in both season (2015-2016) 
(g)

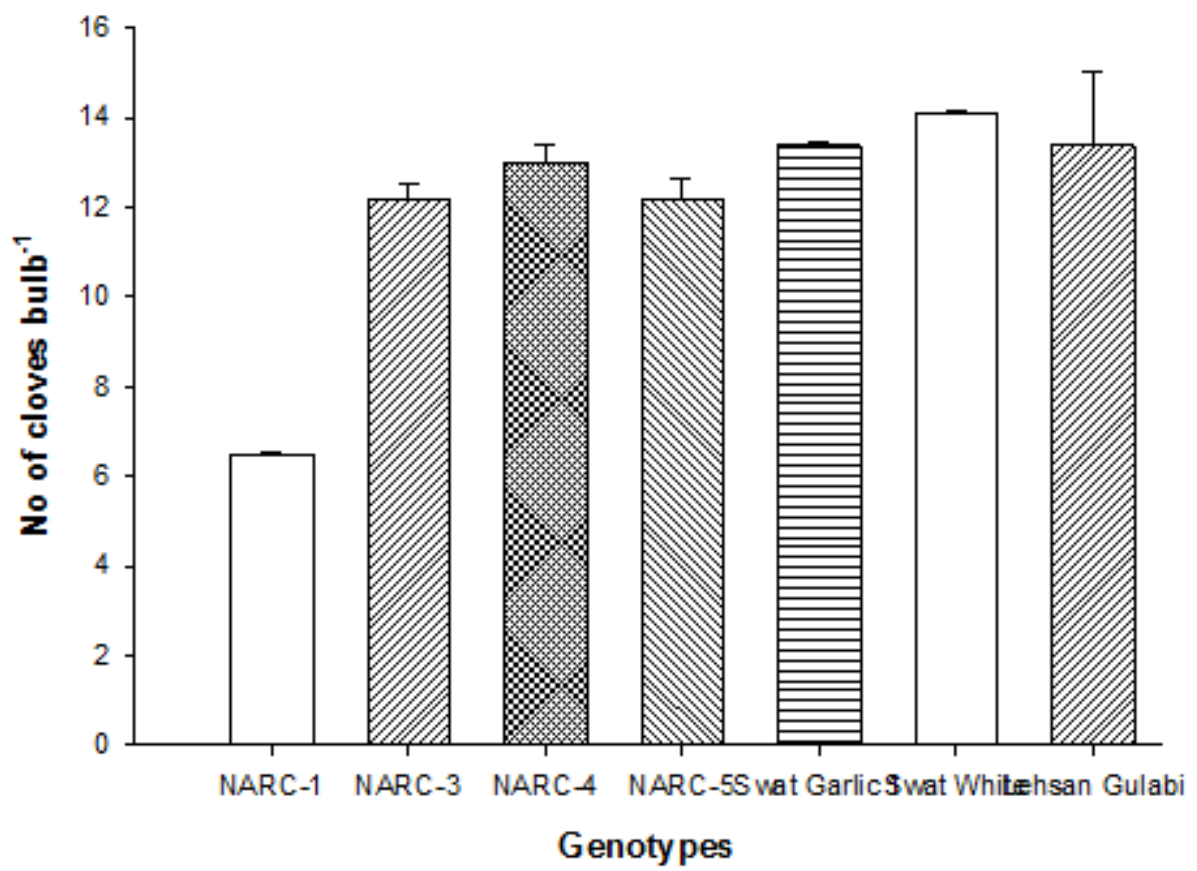

Figure 7. Mean data of No. of cloves bulb ${ }^{-1}$ of different genotypes in both season (20152016)

(h)

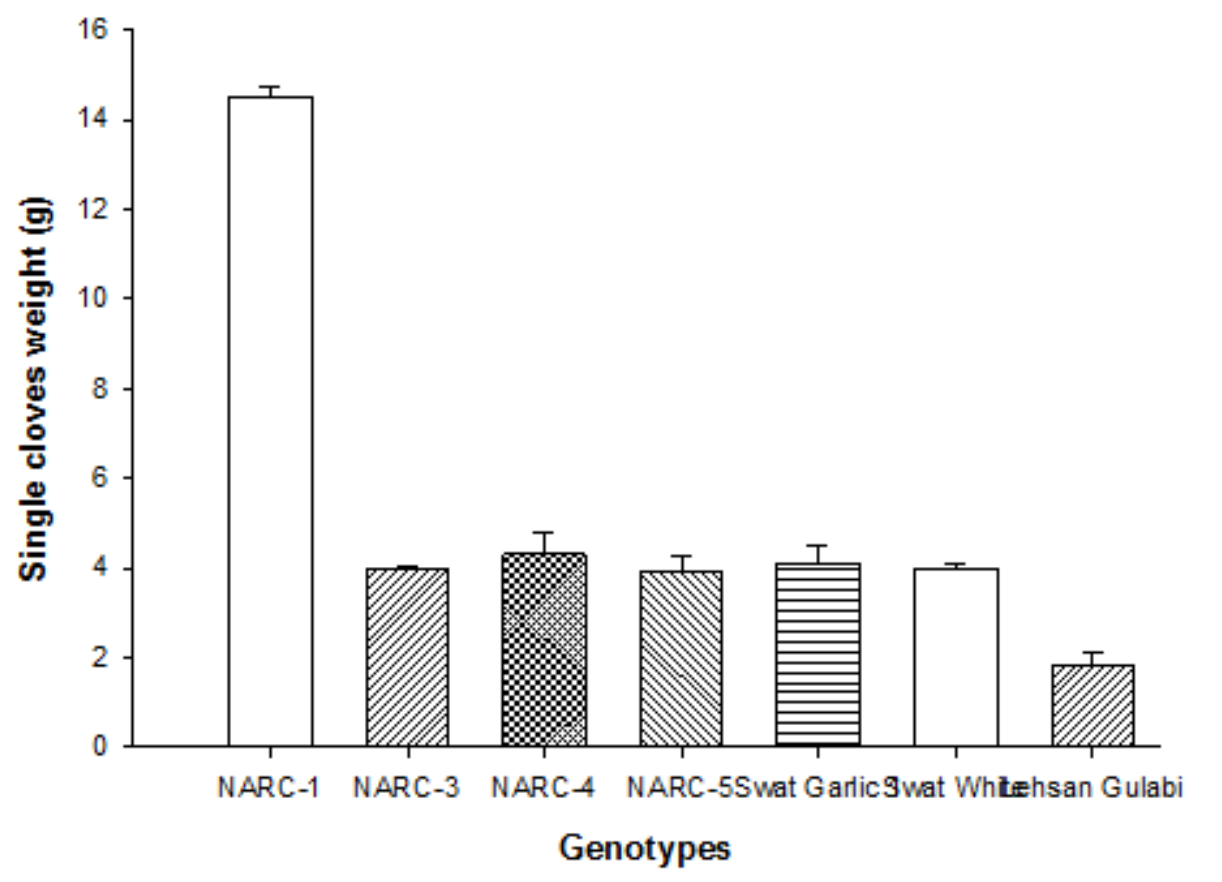

Figure 8. Mean data of Single clove weight (g) of different genotypes in both season (20152016) 


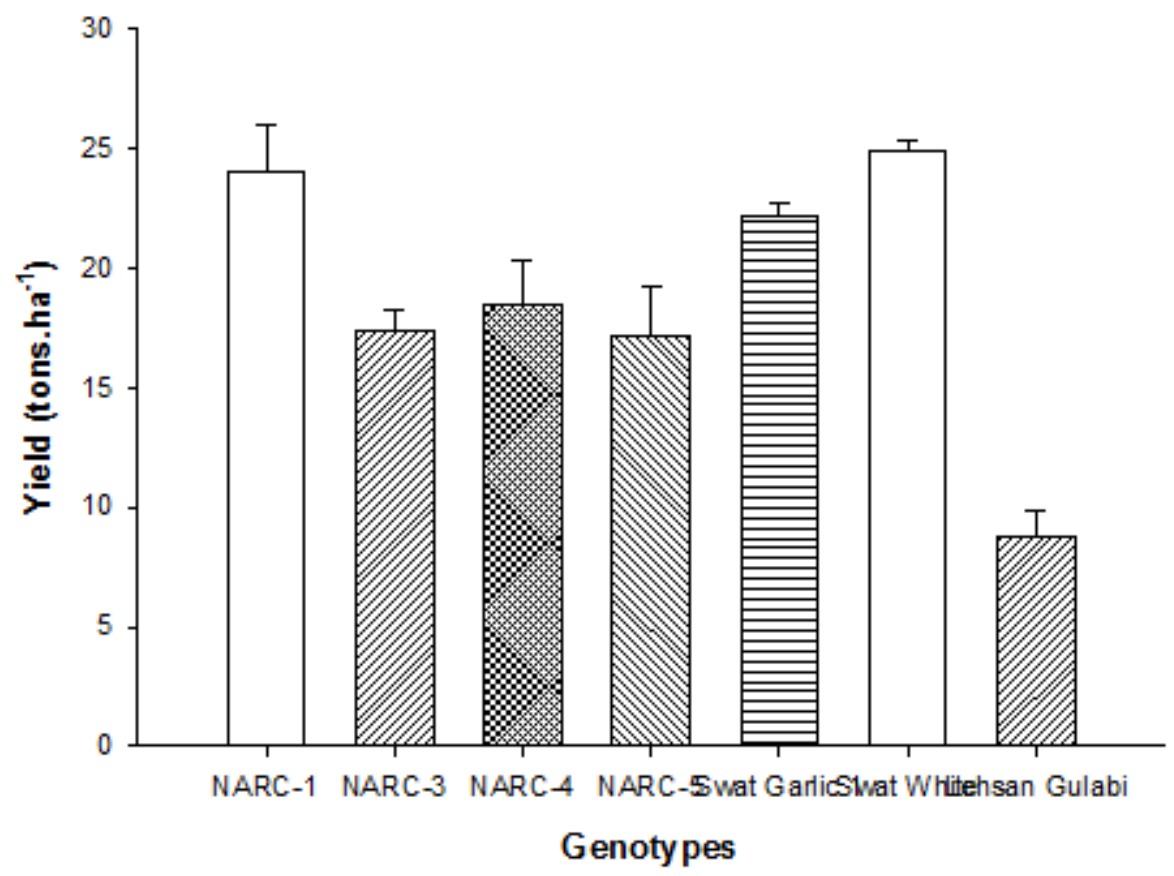

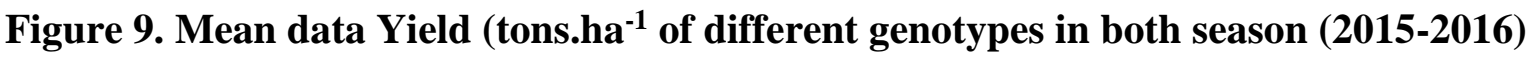

Conclusion and recommendations

New genotypes performed better in all yield contributing parameters and produced 2-3 times higher yield than the local cultivar. The existing cultivar should be replaced with new genotypes to improve garlic bulb yield.

\section{Authors' contributions}

Conceived and designed the experiments: $\mathrm{NH}$ Khan \& S Khan, Performed the experiments: I Hussain, Analyzed the data: S Khan \& I Hussain, Contributed materials/ analysis/tools: R Gul \& SU Haq, Wrote the paper: NH Khan, SU Haq \& S Saleem.

\section{References}

1. Ipek M, Ipek A, Almquist SG \& Simon PW (2005). Determination of linkage and development of the first lowdensity genetic map of garlic based on AFLP markers. Theor Appl Genet 110: 228-236

2. Medina JDLC \& Garcia HS (2007). Garlic: Post-harvest Operation. INPHO; Post-harvest Compendium. FAO

3. Dickerson GW \& Wall MM (1997). Varietal Evaluation of Garlic in New
Mexico. New Mexico State University; Agricultural Experiment Station; Research Report, 717.

4. Osman SAM, Ata ATM \& Gad El-Hak SENH (2007). Morphological, germination, bolting and cytogenetical characteristics of fourteen promising garlic genotypes. African Crop Sci Conf Proc 8: 2005-2012

5. Simon PW (2001). The origins and distribution of garlic: how many garlics are there? US Dept Agr, Agr Res Service, Veg Crop Res Unit, Dept. Hort., Univ Wisconsin, Madison.

6. Singh $Y$ \& Chand R (2003). Performance studies of some garlic (Allium sativum L.) clones. Himachal $J$ Agr Res 29(1\&2): 35-42.

7. Jan MT, Shah P, Hollington PA, Khan MJ \& Sohail Q (2009). Agriculture Research: Design and Analysis a Monograph. NWFP Agricultural Univ Peshawar Pak.

8. Ijaz U, Ullah S, Shah TI, Najeebullah M \& Niaz S. 2015. Genetic association and assessment of variability in garlic. Inter J of Veg Sci 21(2): 141-147. 
9. Thakur JC, Bhatal GS \& Gill SPS (1997). Genetic variability and correlation studies in garlic. $J$ Res Punjab Agr Univ 34(1): 40-44.

10. Haydar A, Sharkar N, Ahmend MB, Hannam MM, Razvy MA, Hossain M, Haque A \& Karim S (2007). Genetic variability and interrelationship in onion (Allium cepa L.). Middle-East J Sci Res 2(3-4): 132-134.

11. Mohammadi B, Khodadadi M, Karami E \& Shaaf S (2014). Variation in agromorphological characters in Iranian garlic landraces. Inter $\mathrm{J}$ of $\mathrm{Veg} \mathrm{Sci}$ 20(3): 202-215.

12. Ayalew A, Tadesse D, Medhin ZG \& Fantaw S (2015). Evaluation of garlic (Allium sativm L.) varieties for bulb yield and growth at Dabat, Northwestern Ethiopia. Open Access Library J 2(01): 1

13. Brewster JL (1997). Onion and Garlic. pp. 581-619. In: Wein, HC, ed, The Physiology of Vegetable Crops. $C A B$ International, Wallingford, UK.

14. Rana MK \& Hore JK (2015).Onion. In: Technology for vegetable production. Rana, M.K., (ed.,) Kalyani publishers, New Delhi, India

15. Volk GM \& Stern D (2009). Phenotypic characteristics of ten garlic cultivars grown at different North American locations. Hort Sci 44(5): 1238-1247.
16. Fanaei H, Narouirad M, Farzanjo M \& Ghasemi M (2014). Evaluation of yield and some agronomic traits in garlic genotypes (Allium sativum L.). Ann Res and Rev in Biol 4(22): 3386-3391.

17. Voigt CE (2014). Glorious garlic, herb of the year 2004. Virginia Cooperative Extension, Virginia State University, USA.

18. Conci VC, Canavelli A, Lunello P, DiRienzo J, Nome SF, Zumelzu G \& Italia R (2003). Yield losses associated with virus-infected garlic plants during five successive years. Plant Dis 87: 1411-1415

19. Lot H, Chovelon V, Souche S \& Delecolle B (1998). Effects of onion yellow dwarf and leek yellow stripe viruses on symptomatology and yield loss of three French garlic cultivars. Plant Dis 82: 1381-1385

20. Melo PD, Resende RO, Cordeiro CMT, Buso JA, Torres AC \& Dusi AN (2006). Viral reinfection affecting bulb production in garlic after seven years of cultivation under field conditions. Eur J Plant Pathol 116: 95-101.

21. Panthee DR, KC RB, Regmi HN, Subedi PP, Bhattarai S \& Dhakal J (2006). Diversity analysis of garlic (Allium sativum L.) germplasm available in Nepal based on morphological characters. Genet Resour Crop Evol 53: 205-212. 